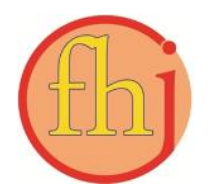

Faletehan Health Journal, 8 (3) (2021) 173-181

www. journal.Ippm-stikesfa.ac.id/ojs/index.php/FHJ

ISSN 2088-673X | e-ISSN 2597-8667

\title{
Literatur Review: Pengaruh Pemberian Supplement Folamil dan Tablet Zat Besi pada Ibu Hamil dengan Anemia terhadap Peningkatan Kadar Hemoglobin
}

\author{
Honaryati ${ }^{1 *}$, Nilawati Usman ${ }^{1}$, Mardiana Ahmad ${ }^{1}$ \\ ${ }^{1}$ Program Studi Ilmu Kebidanan, Sekolah Pascasarjana Universitas Hasanuddin, Makassar \\ *Correspondence Author: honaryati20p@student.unhas.ac.id; yatihonar@gmail.com
}

\begin{abstract}
Abstrak
Anemia kehamilan adalah defisiensi besi yang berperan dalam pembentukan hemoglobin yaitu protein, besi, vitamin B12, vitamin C dan asam folat. Asam folat berperan dalam metabolisme asam amino yang diperlukan dalam pembentukan sel darah merah untuk mencegah terjadinya cacat janin dan anemia. Penelitian ini merupakan studi literatur yang bersifat deksriptif. Penelusuran artikel menggunakan aplikasi Mendeley dengan tahun publikasi dari 2017 sampai dengan 2021 dan mendapatkan 10 artikel yang relavan berdasarkan kriteria inklusi. Dari 10 artikel yang eligibel dan memenuhi kriteria yang telah ditentukan, pemberian suplemen folamil dan tablet zat besi terhadap ibu hamil dengan anemia memiliki pengaruh yang signifikan terhadap peningkatan kadar haemoglobin. Selama kehamilan, ibu hamil mendapatkan asupan nutrisi yang kurang baik serta memiliki persediaan zat besi dan asam folat yang tidak mencukupi. Tenaga kesehatan khususnya bidan sebaiknya meningkatkan cakupan pemberian suplemen folamil dan zat besi dengan cara meningkatkan peran serta masyarakat dan ibu hamil dalam upaya peningkatan pemanfaatan fasilitas kesehatan.
\end{abstract}

Kata Kunci: Suplemen Folamil, Tablet Fe, Ibu Hamil, Anemia, Haemoglobin

\section{Literature review: Effects of Supplementing Folamil and Iron Tablets in Pregnant Women with Anemia on the Increase of Hemoglobin Level}

\begin{abstract}
Anemia in pregnancy is a deficiency of iron that plays a role in the formation of hemoglobin, namely protein, iron, vitamin B12, vitamin Cand folic acid. Folic acid plays a role in the metabolism of amino acids necessary in the formation of red blood cells to prevent from the occurrence of birth defects and anemia. This was a descriptive literature study. The articles search used Mendeley app with the year of publication from 2017 to 2021 and obtained 10 articles that are relavant with inclusion criteria. According to the 10 articles that are eligiable and meet the determined criteria, the provision of folamil supplement and iron tablets to pregnant women with anemia had a significant effect on the increase of hemoglobin level. During pregnancy, the pregnant women got poor nutrients intake and had insufficient supplies of iron and folic acid. Health workers especially midwives should increase the scope of folamil supplement and iron tablets administration by improving the role of community and pregnant women in order to increase the use of health facility. Keywords: Folamil Supplements, Fe Tablets, Pregnant Women, Anemia, Haemoglobin
\end{abstract}




\section{Pendahuluan}

Anemia dalam kehamilan merupakan masalah kesehatan global yang telah mempengaruhi hampir setengah dari wanita hamil(Achebe \& Gafter-Gvili, 2017; World Health Organization, 2015). Organisasi Kesehatan Dunia (WHO) mendefinisikan anemia kehamilan sebagai hemoglobin $(\mathrm{Hb})$ kurang dari $11 \mathrm{~g} / \mathrm{dL}$, atau hematocrit <33\% saat selama kehamilan. Pusat Pengendalian dan Pencegahan Penyakit mendefinisikan anemia dalam kehamilan sebagai $\mathrm{Hb}<11 \mathrm{~g} / \mathrm{dL}$, atau hematokrit, $<33 \%$ pada trimester pertama dan ketiga, dan , $<10,5 \mathrm{~g} / \mathrm{dL}$ atau hematokrit,$<32 \%$ pada trimester kedua. trimester. World Health Organization (WHO) mendefinisikan anemia berat pada semua orang sebagai $\mathrm{Hb}<7 \mathrm{~g} / \mathrm{dL}$ dan anemia sangat berat sebagai $\mathrm{Hb}<4 \mathrm{~g} / \mathrm{dl}$ (World Health Organisation \& WHO, 2011).

Secara global, penyebab anemia yang paling umum dalam kehamilan adalah defisiensi besi yang berfungsi dalam proses pembentukan hemoglobin seperti protein, besi, vitamin B12, vitamin C dan asam folat. Vitamin B12 dibutuhkan untuk dalam prose pengaktifpan asam folat dan metabolisme sel, terutama bagian sel saluran pencerna, sumsum tulang dan jaringan syaraf. Asam folat ini juga berperan dalam proses metabolisme asam amino yang diperlukan dalam proses pembentukan sel darah merah (Al-Khaffaf et al., 2020; Horowitz et al., 2013; Stephen et al., 2018). Juga berperan dalam pencegahan cacat bawaan, selain itu juga berperan dalam neuro kognitif (Sulhub, et all, 2000). Asam folat sangat penting untuk mencegah terjadinya cacat janin dan anemia.

Menurut Survei Demografi dan Kesehatan Indonesia (SDKI) dilaporkan angka kematian Ibu (AKI) pada tahun 2010 yaitu 228/100.000 kelahiran hidup kemudian meningkat pada tahun 2012 yaitu 359/100.000 kelahiran hidup. Pada Ibu hamil yang mengalami anemia memiliki risiko kematian hingga 3,6 kali lebih besar dibandingkan dengan ibu hamil yang tidak mengalami anemia. Anemia juga memiliki kontribusi yang tinggi terhadap kematian di Indonesia dengan persentase mencapai $50-70 \%$. Selain itu, ibu hamil yang menderita anemia dapat berdampak terhadap janin, seperti bayi lahir prematur, risiko bayi berat lahirrendah (BBLR), kelainan janin, dan meningkatkan risiko gawat janin (Badan Penelitian dan Pengembangan Kesehatan, 2013a). Angka kejadian anemia di Indonesia masih sangat tinggi. Dalam penelitian Dewa ayu Surinati, melaporkan bahwa angka kejadian anemia yang disebabkan kekurangan asam folat adalah sebesar $29 \%$.

Anemia defisiensi besi dan asam folat disebabkan karena asupan nutrisi yang kurang baik selama kehamilan serta persediaan zat besi dan asam folat yang tidak mencukupi selama kehamilan. Kekurangan zat besi pada ibu hamil dapat dilihat dari besarnya angka kesakitan dan kematian ibu dan janin serta peningkatan risiko berat bayi lahir rendah (BBLR). Anemia defisiensi besi apabila disertai dengan kekurangan mikronutrien penting lainnya akan membuat keadaan ibu lebih buruk. Akibat kekurangan zat gizi selama kehamilan anemia juga diperburuk juga dengan meningkatnya kebutuhan gizi terkait pertumbuhan janin dalam kandungan. Defisiensi zat besi pada ibu hamil menyebabkan asupan zat besi ke janin menurun sehingga dapat menyebabkan persalinan prematur, kecil masa kehamilan dan peningkatan kematian perinatal (Benson et al., 2020; Chang et al., 2013; Ugwu \& Uneke, 2020; Wesström, 2020).

Terapi yang dapat diberikan kepada ibu hamil dengan anemia selain pemberian zat besi juga pemberian suplement asam folat yang berfungsi sebagai pendukung zat besi. Kekurangan asam folat dapat menyebabkan kerusakan pada kromosom, yaitu menginduksi untaian DNA yang istirahat dan hipometilasi pada gen p53, menyebabkan rendahnya kadar folat dan tinggi hemosistein sehingga terjadi penurunan fungsi kognitif. Angka kejadian dan resiko untuk Neural Tube Defect (NTD) beragam dari angka 7,5 sampai 11,6 per 10000 kelahiran hidup. Di Indonesia sendiri belum ada data pasti berapa besarnya prevalensi adanya penyakit kelainan sumsum tulang belakang. Angka turun dari 3,5\% sampai 1\% pada wanita yang secara acak diberikan asam folat 400 mikrogram sebelum kehamilan dan selama 6 minggu pertama kehamilan.

Karena pentingnya zat ini, kebutuhan asam folat untuk ibu hamil harus disiapkan sejak sebelum hamil. Jika dimulai pada satu bulan sebelum kehamilan dan tiga bulan pertama kehamilan akan menurunkan beban resiko bayi lahir terhadap NTD lebih dari 70\% (Ginting et al., 2019). The National Institutes of Health telah menemukan bahwa asam folat dapat menutupi efek kerusakan dari defisiensi vitamin B12 dengan 
Faletehan Health Journal, 8 (3) (2021) 173-181

www. journal.Ippm-stikesfa.ac.id/ojs/index.php/FHJ

ISSN 2088-673X | 2597-8667

memperbaiki anemia megaloblastik yang disebabkan oleh kekurangan vitamin B12 tanpa memperbaiki kerusakan neurologis yang juga terjadi. Hasil Riskesdas (2013) melaporkan bahwa kejadian anemia pada ibu hamil di Indonesia sebesar 37,1\% (Badan Penelitian dan Pengembangan Kesehatan, 2013b) mengalami peningkatan 48,9\% pada tahun 2018 (RISKESDAS, 2018).

Berdasarkan latar belakang diatas peneliti tertarik untuk membahas lebih dalam mengenai pengaruh pemberian supplement folamil dan zat besi pada ibu hamil dengan anemia terhadap peningkatan kadar hemoglobin dalam bentuk studi literatur yang bersifat deskriptif.

\section{Metodologi Penelitian}

Jenis penelitian merupakan studi literatur atau tinjauan pustaka. Adapun sifat dari penelitian ini adalah analisis deskriptif, yaitu menjelasakan secara teratur data yang telah diperoleh, kemudian diberikan pemahaman dan penjelasan agar dapat dipahami dengan baik oleh pembaca.

Literature review ini disusun melalui penelusuran artikel ilmiah menggunakan aplikasi Mendeley dengan memasukkan kata kunci "iron and folic acid supplementation in pregnant women" didapatkan sebanyak 1.138 artikel. Setelah dilakukan filterisasi tahun terbit yaitu 2017-2021 didapatkan 402 artikel. Selanjutnya di lakukan seleksi terkait abstrak, full text, open akses jenis penelitian, dan duplikasi didapatkan 27 artikel Proses akhir yaitu membaca dan memilih artikel yang eligibility berdasarkan kriteria didapatkan 10 artikel yang relavan (Tabel 1). Artikel dievaluasi berdasarkan:

1. Kriteria Inklusi
A. Artikel membahas tentang supplement zat besi dan asam folat pada ibu hamil
B. Tahun publikasi 2017-2021
C. Publikasi Internasional dan Nasional
D. Jurnal Nasional memilki ISSN
E. Artikel menggunakan bahasa Inggris dan Indonesia
F. Original artikel, abstrak, full text dan open akses

2. Kriteria Eksklusi

a. Artikel selain bahasa Inggris

b. Jenis penelitian literature review, RCT gambar 1.

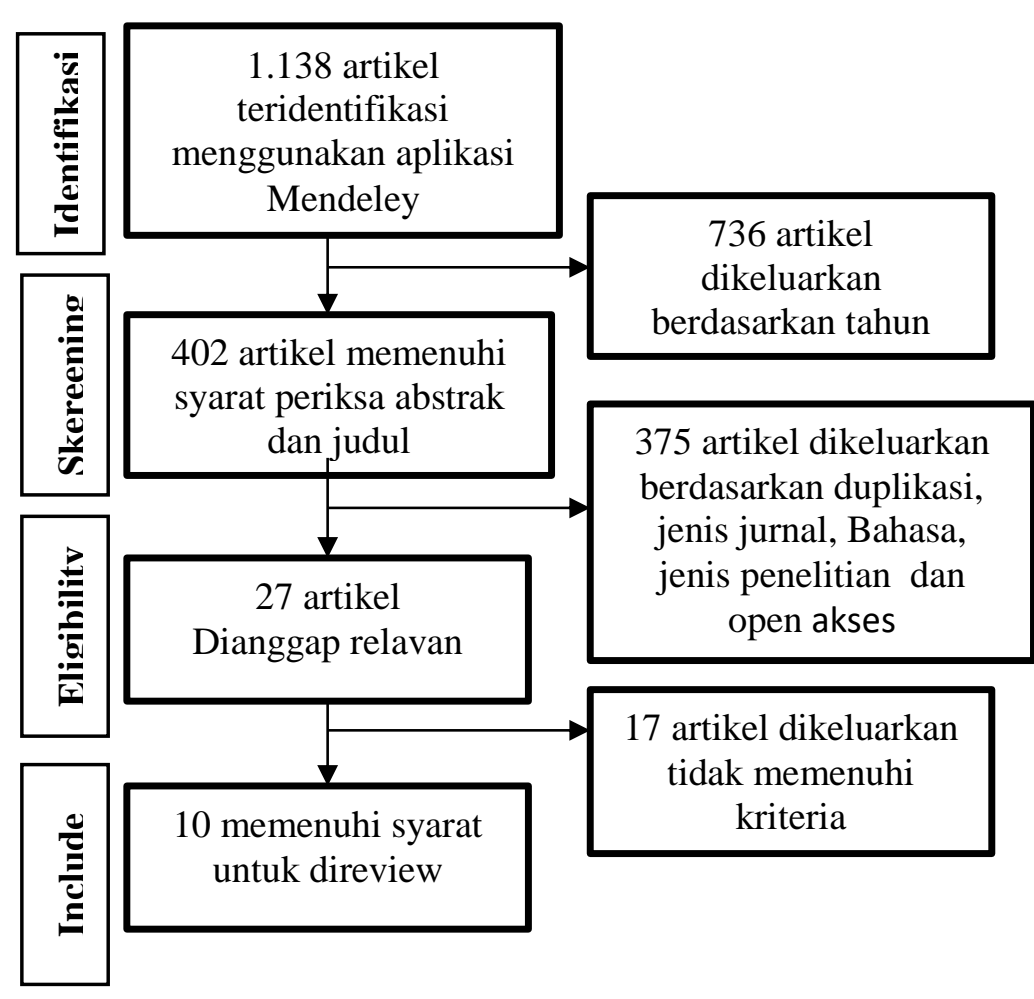

Gambar 1. Flow Chart Penulusuran Artikel

\section{Hasil dan Pembahasan}

Literature Review ini di sintesis menggunakan metode naratif dengan mengelompokkan data-data hasil ekstraksi yang sejenis sesuai dengan hasil yang diukur untuk menjawab tujuan. Jurnal penelitian yang sesuai dengan kriteria inklusi kemudian dikumpulkan dan dibuat ringkasan jurnal meliputi nama peneliti, tahun terbit jurnal, judul penelitian, metode dan ringkasan hasil atau temuan.

Ringkasan jurnal penelitian tersebut dimasukan ke dalam tabel sesuai dengan format tersebut di atas. Untuk lebih memperjelas analisis abstrak dan full text jurnal dibaca dan dicermati. Ringkasan jurnal tersebut kemudian dilakukan analisis terhadap isi yang terdapat dalam tujuan penelitian dan hasil/temuan penelitian.

Analisis isi jurnal, kemudian dilakukan koding terhadap isi jurnal yang direview berdasarkan garis besar atau inti dari penelitian tersebut yang dilakukan dengan mengurai dalam sebuah kalimat kemudian jika sudah terkumpul kemudian dicari persamaan dan perbedaan pada masing-masing penelitian lalu dibahas untuk menarik kesimpulan. 
Tabel 1. Ekstraksi Hasil Penelitian

\begin{tabular}{|c|c|c|c|c|c|}
\hline No & Penulis/Tahun & Judul & $\begin{array}{c}\text { Jenis } \\
\text { Penelitian }\end{array}$ & Sampel & Analisis Data \\
\hline 1 & $\begin{array}{l}\text { (Kamau et al., } \\
\text { 2019) }\end{array}$ & $\begin{array}{l}\text { Effect of community } \\
\text { based health education on } \\
\text { knowledge and attitude } \\
\text { towards iron and folic } \\
\text { acid supplementation } \\
\text { among pregnant women } \\
\text { in Kiambu County, } \\
\text { Kenya: A quasi } \\
\text { experimental study }\end{array}$ & $\begin{array}{l}\text { Quasi- } \\
\text { Experimental } \\
\text { Pretest- } \\
\text { Posttest }\end{array}$ & $\begin{array}{lr}\text { Sampel } & 340 \\
\text { wanita } & \text { hamil, } \\
\text { umur } & 18-49 \\
\text { tahun } & \end{array}$ & $\begin{array}{l}\text { Menggunakan } \\
\text { STATA }\end{array}$ \\
\hline
\end{tabular}

Effect of routine ironfolic acid supplementation among

2 (Ahmed et al., rural pregnant women 2019) living in low- And highgroundwater-iron areas in Bangladesh
Sampel 260 ibu hamil yang Desain studi longitudinal prospektif tinggaldi dataran rendah dan 262 terkontrol daerah dataran tinggi.
Pelaksanaan pendidikan kesehatan berbasis masyarakat meningkatkan pengetahuan ibu, sikap positif dan proporsi ibu hamil yang diberi konseling zat besi dan supplement asam folat mengalami peningkatan yang lebih baik pada kelompok intervensi.

Suplementasi zat besi dan asam folat secara signifikan meningkatkan konsentrasi $\mathrm{Hb}$ pada ibu hamil yang tinggal di daerah pedesaan dataran Analisis tinggi dan rendah Anova Suplementasi rutin dengan $60 \mathrm{mg}$ Fe dan 400 $\mathrm{g}$ asam folat tidak menimbulkan risiko hemokonsentrasi atau kelebihan $\mathrm{Fe}$ yang signifikan.

Pengawasan mingguan

Effect of directly observed oral iron

(Ahamed et al., supplementation during pregnancy on iron status in a rural population in Haryana: A randomized controlled trial

A community-based cluster randomised controlled trial in rural Bangladesh to evaluate

4 (Huda et al., the impact of the use of 2018) iron-folic acid supplements early in pregnancy on the risk of neonatal mortality: The Shonjibon trial Karakteristik Ibu, terkontrol kelahiran hidup
Uji coba Sampel 30,000 uji coba acak terkontrol
Independen $\mathrm{t}$ - efektif test dan meningkatkan kepatuhan sebanyak 400 Mannibu hami suplementasi besi dan asam folat dan kadar
Whitney test hemoglobin darah

Suplemen zat besi dan asam folat yang dimulai pada trimester pertama $\begin{array}{llr}\text { Analisis } & \text { kehamilan } & \text { dapat } \\ \text { deskriptif, } \chi^{2} & \text { mengurangi } & \text { kematian }\end{array}$ uji atau uji neonatal di bulan pertama Fisher's Exact kehidupan.

\begin{tabular}{|c|c|c|c|c|c|c|}
\hline 5 & $\begin{array}{l}\text { (Putri } \\
2020)\end{array}$ & $\begin{array}{l}\text { Hubungan antara } \\
\text { Karakteristik Ibu, } \\
\text { Kecukupan Asupan Zat } \\
\text { Besi, Asam Folat dan } \\
\text { Vitamin C dengan Status } \\
\text { Anemia pada Ibu Hamil } \\
\text { di Kecamatan Jatinangor }\end{array}$ & $\begin{array}{l}\text { Penelitian } \\
\text { cros- } \\
\text { sectional }\end{array}$ & $\begin{array}{l}\text { Teknik } \\
\text { pengambilan } \\
\text { sampel } \\
\text { accidental } \\
\text { sampling } \\
\text { dengan sampel } \\
66 \text { ibu hamil }\end{array}$ & $\begin{array}{l}\text { Analisis } \\
\text { menggunakan } \\
\text { uji koefisien } \\
\text { kontingensi }\end{array}$ & $\begin{array}{l}\text { Tidak terdapat hubungan } \\
\text { antara karakteristik ibu, } \\
\text { asupan zat besi, asam } \\
\text { folat dan vitamin C } \\
\text { dengan status anemia } \\
\text { pada ibu hamil ibu hamil } \\
\text { di Kecamatan Jatinangor }\end{array}$ \\
\hline 6 & $\begin{array}{l}\text { (Oiye et al., } \\
2020)\end{array}$ & $\begin{array}{l}\text { The Influence of } \\
\text { Antenatal Oral Iron and } \\
\text { Folic Acid Side Effects on }\end{array}$ & $\begin{array}{l}\text { Penelitian } \\
\text { deskriptif }\end{array}$ & $\begin{array}{l}\text { Sampel } 277 \\
\text { ibu hamil }\end{array}$ & $\begin{array}{l}\text { Shapiro-Wilk } \\
\text { test, Mann- } \\
\text { Whitney }\end{array}$ & $\begin{array}{l}\text { Pemberian zat besi dan } \\
\text { supplement zat besi dapat } \\
\text { meningkatkan kadar } \mathrm{Hb} \text {, }\end{array}$ \\
\hline
\end{tabular}


Faletehan Health Journal, 8 (3) (2021) 173-181

www. journal.Ippm-stikesfa.ac.id/ojs/index.php/FHJ

ISSN 2088-673X | 2597-8667

\begin{tabular}{|c|c|c|c|c|c|c|}
\hline & & $\begin{array}{l}\text { Supplementation } \\
\text { Duration in Low- } \\
\text { Resource Rural Kenya: A } \\
\text { Cross-Sectional Study }\end{array}$ & $\begin{array}{l}\text { cross- } \\
\text { sectional }\end{array}$ & & U test & $\begin{array}{l}\text { akan tetapi adanya efek } \\
\text { samping seperti mual } \\
\text { yang mempengaruhi } \\
\text { kpeatuhan dalam } \\
\text { konsumsi supplement. }\end{array}$ \\
\hline 7 & $\begin{array}{l}\text { (NGETHE et } \\
\text { al., 2020) }\end{array}$ & $\begin{array}{l}\text { Relationship between } \\
\text { compliance to Iron and } \\
\text { Folic Acid } \\
\text { Supplementation and } \\
\text { Anaemia among Pregnant } \\
\text { Women in Nyeri County, } \\
\text { Kenya }\end{array}$ & $\begin{array}{l}\text { Mixed } \\
\text { methods } \\
\text { study }\end{array}$ & $\begin{array}{l}\text { Sampel } 385 \\
\text { ibu hamil }\end{array}$ & Uji chi-square & $\begin{array}{l}\text { Peningkatan prevalensi } \\
\text { anemia pada ibu hamil } \\
\text { berhubungan dengan } \\
\text { tingginya ketidakpatuhan. } \\
\text { Oleh karena itu, wanita } \\
\text { hamil harus sadar tentang } \\
\text { pentingnya konsumsi } \\
\text { suplemen zat besi dan } \\
\text { asam folat. }\end{array}$ \\
\hline 8 & $\begin{array}{l}\text { (Ng'the et al., } \\
\text { 2021) }\end{array}$ & $\begin{array}{l}\text { Nutrition counselling and } \\
\text { knowledge on iron and } \\
\text { folic acid } \\
\text { supplementation among } \\
\text { pregnant women in Nyeri } \\
\text { County, Kenya }\end{array}$ & Mix-Method & $\begin{array}{l}\text { Sampel } 385 \\
\text { ibu hamil }\end{array}$ & $\begin{array}{l}\text { chi-square } \\
\text { analysis }\end{array}$ & $\begin{array}{l}\text { Ibu hamil memiliki } \\
\text { pengetahuan yang baik } \\
\text { tentang gizi yang dapat } \\
\text { meningkatkan } \\
\text { hemoglobin }\end{array}$ \\
\hline 9 & $\begin{array}{l}\text { (Tinago et al., } \\
\text { 2017) }\end{array}$ & $\begin{array}{l}\text { Individual and structural } \\
\text { environmental influences } \\
\text { on utilization of iron and } \\
\text { folic acid } \\
\text { supplementation among } \\
\text { pregnant women in } \\
\text { Harare, Zimbabwe }\end{array}$ & $\begin{array}{l}\text { Qualitative } \\
\text { research }\end{array}$ & $\begin{array}{l}\text { Sampel ibu } \\
\text { hamil } 24 \text { orang } \\
\text { dan petugas } \\
\text { kesehatan } 14 \\
\text { orang }\end{array}$ & $\begin{array}{l}\text { Data } \\
\text { dianalisis } \\
\text { secara tematis } \\
\text { menggunakan } \\
\text { NVivo } 10 .\end{array}$ & $\begin{array}{l}\text { Pendekatan untuk } \\
\text { meningkatkan } \\
\text { penggunaan } \\
\text { suplementasi } \\
\text { mikronutrien untuk } \\
\text { menurunkan kematian ibu } \\
\text { dan meningkatkan } \\
\text { kesehatan ibu dan anak } \\
\text { secara keseluruhan di } \\
\text { Zimbabwe }\end{array}$ \\
\hline 10 & $\begin{array}{l}\text { (Schulze et al., } \\
\text { 2019) }\end{array}$ & $\begin{array}{l}\text { Antenatal } \\
\text { Micronutrient } \\
\text { Supplementation } \\
\text { Compared to Iron-Folic } \\
\text { Acid } \\
\text { Micronutrient } \\
\text { Dtatus but } \\
\text { Does Not Eliminate } \\
\text { Deficiencies in a } \\
\text { Randomized Controlled } \\
\text { Trial Among Pregnant } \\
\text { Women of Rural } \\
\text { Bangladesh }\end{array}$ & $\begin{array}{l}\text { Survei uji } \\
\text { coba } \\
\text { terkontrol }\end{array}$ & $\begin{array}{l}1.526 \\
\text { hamil }\end{array}$ & $\begin{array}{l}\text { Analisis chi- } \\
\text { kuadrat, uji t } \\
\text { untuk variabel } \\
\text { kontinu }\end{array}$ & $\begin{array}{l}\text { Suplementasi prakonsepsi } \\
\text { diperlukan untuk } \\
\text { memenuhi kebutuhan } \\
\text { nutrisi kehamilan pada } \\
\text { populasi yang kekurangan } \\
\text { gizi. }\end{array}$ \\
\hline
\end{tabular}

Dalam melakukan data Abstraksi data peneliti didampingi oleh dua orang pembimbing secara bersamaan meninjau dan membaca dengan lengkap artikel yang relavan, kemudian diskusi untuk menyepakati keputusan artikel yang disesuaikan dengan kriteria inklusi.

Sepuluh artikel yang dipilih berdasarkan kriterian inklusi yang membahas mengenai tentang pengaruh pemberian supplement folamil dan zat besi pada ibu hamil dengan anemia terhadap peningkatan kadar Hemoglobin. Hasil Ekstraksi penelitian dapat dilihat pada table 1 .

\section{Pembahasan}

Kebutuhan zat besi pada ibu hamil selain untuk kebutuhan ibu sendiri, akan meningkat seiring dengan kebutuhan zat besi untuk perkembangan janin dan placenta, dan cadangan untuk kehilangan sel darah merah saat melahirkan. Anemia zat besi dapat disebabkan karena kurangnya asupan zat besi melalui makanan seharihari yang tidak mencukupi kebutuhan fisiologis.

Penyebab anemia pada ibu hamil di Indonesia tidak hanya disebabkan oleh kekurangan zat besi tetapi juga karena kurangnya nutrisi lain yang 
berperan dalam penyerapan zat besi dan pembentukan Hemoglobin. Ibu hamil merupakan kelompok risiko anemia karena rendahnya simpanan zat besi dalam tubuh, sehingga World Health Organization merekomendasikan pemberian diberikan sedini mungkin dengan dosis harian suplemen $60 \mathrm{mg}$ Besi dan $400 \mathrm{~g}$ Asam Folat selama kehamilan, namun pada kenyataanya penggunaan supplement dikalangan ibu hamil masih rendah yang disebabkan berbagai factor(Assefa et al., 2019; WHO et al., 2012; World health organisation, 2016).

Dalam tinjaun sistimatis didapatkan 10 artikel yang eligiabel untuk dilakukan review, dari rangkuman artikel tersebut didapatkan bahwa pemberian suplemen zat besi dan asam folat pada ibu hamil dengan anemia dapat meningkatkan kadar hemoglobin. Tablet zat besi (Fe) merupakan tablet mineral yang diperlukan oleh tubuh untuk pembentukan sel darah merah atau hemoglobin. Unsur Fe merupakan unsur paling penting untuk pembentukan sel darah merah. Zat besi secara alamiah didapatkan dari makanan. Jika ibu hamil kekurangan zat besi pada menu makanan yang dikonsumsinya sehari-hari, dapat menyebabkan gangguan anemia gizi (kurang darah).

Kebutuhan tablet besi pada ibu hamil yaitu sebesar 200-600 mg untuk memenuhi peningkatan massa sel darah merah, 200-370 mg untuk janin yang bergantung pada berat lahirnya, 150-200 mg untuk kehilangan eksternal, 30-170 mg untuk tali pusat dan plasenta, 90-310 mg untuk menggantikan darah yang hilang saat melahirkan. Sehingga kebutuhan total zat besi pada kehamilan berkisar antara 440-1050 mg dan 580-1340 mg dimana kebutuhan tersebut akan hilang $200 \mathrm{mg}$ melalui ekskresi kulit, usus, urinarius. Untuk mengatasi kehilangan ini, ibu hamil memerlukan rata-rata 30,00-40,00 mg zat besi per hari. Kebutuhan ini akan meningkat secara signifikan pada trimester terakhir, yaitu rata-rata 50,00 mg / hari pada akhir kehamilan menjadi 60,00 mg / hari (Noviyana, 2019; Varghese et al., 2019).

Zat besi yang tersedia dalam makanan berkisar 6,00 sampai 9,00 mg/hari, ketersediaan ini bergantung pada cakupan diet. Karena itu, pemenuhan kebutuhan pada kehamilan memerlukan mobilisasi simpanan zat besi dan peningkatan absorbsi. Pemberian tablet zat besi selama kehamilan merupakan salah satu cara yang paling cocok bagi ibu hamil untuk meningkatkan kadar $\mathrm{Hb}$ sampai tahap yang di inginkan, karna sangat epektif dimana satu tablet mengandung 60 mg Fe. Setiap tablet setara dengan 200mg ferrosulfat. Selama kehamilan minimal di berikan 90 tablet sampai 42 minggu setelah melahirkan di berikan sejak pemeriksaan ibu hamil pertama.

Pemberian preparat $60 \mathrm{mg} / \mathrm{hari}$ dapat menaikan kadar Hb sebanyak 1 gr\%/ bulan. Saat ini program nasional menganjurkan kombinasi $60 \mathrm{mg}$ besi dan 50 nanogram asam folat untuk profilaksis anemia. Besi mempunyai beberapa fungsi esensial di dalam tubuh yaitu sebagai alat angkut oksigen dari paru-paru ke jaringan tubuh, sebagai alat angkut elektrondi dalam sel, dan sebagai bagian terpadu berbagai reaksi enzim di dalam jaringan tubuh. Rata-rata kadar besi dalam tubuh sebesar 34 gram. Sebagian besar ( \pm 2 gram $)$ terdapat dalam bentuk hemoglobin dan sebagian kecil $( \pm 130 \mathrm{mg})$ dalambentuk mioglobin. Simpanan besi dalam tubuh terutama terdapat dalam hati dalam bentuk feritin dan hemosiderin. Dalam plasma, transferin mengangkut $3 \mathrm{mg}$ besi untuk dibawa ke sumsum tulang untuk eritropoesis dan mencapai $24 \mathrm{mg}$ per hari. Sistem retikuloendoplasma akan mendegradasi besi dari eritrosituntuk dibawa kembali ke sumsum tulang untuk eritropoesis. Zat besi adalah mineral yang dibutuhkan untuk membentuk sel darahmerah (hemoglobin). Selain itu, mineral ini juga berperan sebagai komponen untuk membentuk mioglobin (protein yang membawa oksigen ke otot), kolagen (protein yang terdapat di tulang, tulang rawan, dan jaringan penyambung), serta enzim. Zat besi juga berfungsi dalam sistim pertahanan tubuh.

Secara umum kebutuhan asam folat pada wanita hamil meningkat dari normal. Kebutuhan asam folat pada wanita usia subur dan ibu hamil sekitar 400-600 mikrogram per hari (0,4-0,6 $\mathrm{mcg} /$ hari). Asam folat sangat berperan penting pada fase awal pembentukan janin, yaitu pada fase pembentukan sistem saraf pusat. Pada pasien yang ingin hamil, perlu dilakukan edukasi prekonsepsi mengenai konsumsi asam folat selama kehamilan. Suplementasi asam folat perikonsepsi dapat menurunkan angka kejadian anemia dalam kehamilan, menurukan resiko untuk terjadinya preeklamsia bagi ibu dan menurunkan angka terjadinya neural tube defects(Birhanu et al., 2018; Wen et al., 2016)), menurunkan efek teratogenik pada janin bagi ibu dalam pengobatan anti kejang, mencegah terjadinya hambatan pertumbuhan janin, dan menurunkan risiko terjadinya autism (Gao et al., 2016; Moussa 
Faletehan Health Journal, 8 (3) (2021) 173-181

www. journal.Ippm-stikesfa.ac.id/ojs/index.php/FHJ

ISSN 2088-673X | 2597-8667

et al., 2016). Penambahan asam folat pada masa kehamilan sangat penting selain dapat mencegah terjadinya kecacatan pada bayi, dapat juga mengurangi berbagai risiko yang terjadi misalnya pre-eklampsia. Angka kecukupan sehari asam folat di Indonesia yang dianjurkan bagi ibu hamil adalah 400 mikrogram per hari.

Asam folat merupakan komponen penting yang harus dipenuhi sebelum kehamilan dan selama masa-masa awal kehamilan untuk mencegah defek tabung saraf serta berbagai abnormalitas kongenital yang terkait dengan asam folat seperti defek jantung, anomali saluran kemih, cleft oral facial, dan defek anggota gerak. Oleh karena itu, pemberian suplementasi asam folat diberikan untuk wanita yang sedang mempersiapkan kehamilan. Semua wanita yang berada dalam usia reproduktif (12-45 tahun) yang masih memiliki kemungkinan untuk hamil disarankan untuk mengkonsumsi asam folat dalam bentuk suplementasi multivitamin dalam kunjungan kesehatanya (Douglas Wilson et al., 2015).

\section{Simpulan}

Pemberian supplement zat besi dan asam folat pada ibu hamil dengan anemia berpengaruh dalam peningkatkan kadar hemoglobin, sehingga diharapkan kepada tenaga Kesehatan khususnya bidan untuk meningkatkan cakupan pemberian supplement folamil dan zat besi dengan cara meningkatkan peran serta masyarakat dan ibu hamil dalam upaya peningkatan pemanfaatan fasilitas Kesehatan.

\section{Referensi}

Achebe, M. M., \& Gafter-Gvili, A. (2017). How I treat anemia in pregnancy: Iron, cobalamin, and folate. Blood. https://doi.org/10.1182/blood-2016-08672246

Ahamed, F., Yadav, K., Kant, S., Saxena, R., Bairwa, M., \& Pandav, C. S. (2018). Effect of directly observed oral iron supplementation during pregnancy on iron status in a rural population in Haryana: A randomized controlled trial. Indian Journal of Public Health, 62(4). https://doi.org/10.4103/ijph.IJPH_313_17

Ahmed, F., Khan, M. R., Chowdhury, I. A., Raqib, R., Roy, A. K., \& Chowdhury, R. (2019). Effect of routine iron-folic acid supplementation among rural pregnant women living in low- And high-groundwateriron areas in Bangladesh. Public Health Nutrition, 22(15). https://doi.org/10.1017/S1368980019001617

Al-Khaffaf, A., Frattini, F., Gaiardoni, R., Mimiola, E., Sissa, C., \& Franchini, M. (2020). Diagnosis of anemia in pregnancy. Journal of Laboratory and Precision Medicine. https://doi.org/10.21037/jlpm.2019.12.03

Assefa, H., Abebe, S. M., \& Sisay, M. (2019). Magnitude and factors associated with adherence to Iron and folic acid supplementation among pregnant women in Aykel town, Northwest Ethiopia. BMC Pregnancy and Childbirth, 19(1). https://doi.org/10.1186/s12884-019-2422-4

Badan Penelitian dan Pengembangan Kesehatan. (2013a). Riset Kesehatan Dasar (RISKESDAS) 2013. Laporan Nasional 2013, 1-384. https://doi.org/1 Desember 2013

Badan Penelitian dan Pengembangan Kesehatan. (2013b). Riset Kesehatan Dasar 2013. Riset Kesehatan Dasar 2013.

Benson, C. S., Shah, A., Frise, M. C., \& Frise, C. J. (2020). Iron deficiency anaemia in pregnancy: A contemporary review. In Obstetric Medicine. https://doi.org/10.1177/1753495X20932426

Birhanu, T. M., Birarra, M. K., \& Mekonnen, F. A. (2018). Compliance to iron and folic acid supplementation in pregnancy, Northwest Ethiopia. BMC Research Notes, 11(1). https://doi.org/10.1186/s13104-018-3433-3

Chang, S., Zeng, L., Brouwer, I. D., Kok, F. J., \& Yan, H. (2013). Effect of iron deficiency anemia in pregnancy on child mental development in rural China. Pediatrics. https://doi.org/10.1542/peds.2011-3513

Gao, Y., Sheng, C., Xie, R. H., Sun, W., Asztalos, E., Moddemann, D., Zwaigenbaum, L., Walker, M., \& Wen, S. W. (2016). New perspective on impact of folic acid supplementation during pregnancy on neurodevelopment/autism in the offspring children - A systematic review. PLoS ONE, 11(11).

https://doi.org/10.1371/journal.pone.0165626

Ginting, B., Surbakti, E., \& Nasution, N. (2019). Hubungan Interaksi Ibu Hamil dan Bidan, Pengetahuan, Sikap Ibu Hamil dengan 
Konsumsi Asam Folat Untuk Mencegah Cacat Bawaan Pada Bayi di Kota Medan Tahun 2012. Jurnal Ilmiah PANNMED (Pharmacist, Analyst, Nurse, Nutrition, Midwivery, Environment, Dentist). https://doi.org/10.36911/pannmed.v7i3.408

Horowitz, K. M., Ingardia, C. J., \& Borgida, A. F. (2013). Anemia in Pregnancy. In Clinics in Laboratory Medicine. https://doi.org/10.1016/j.cll.2013.03.016

Huda, T. M., Rahman, M. M., Raihana, S., Islam, S., Tahsina, T., Alam, A., Agho, K., Rasheed, S., Hayes, A., Karim, M. A., Rahman, Q. S., Siddique, A. B., Moinuddin, M., Chowdhury, M., Ghose, L., Afsana, K., Raynes-Greenow, C., El Arifeen, S., \& Dibley, M. J. (2018). A community-based cluster randomised controlled trial in rural Bangladesh to evaluate the impact of the use of iron-folic acid supplements early in pregnancy on the risk of neonatal mortality: The Shonjibon trial. BMC Public Health, 18(1). https://doi.org/10.1186/s12889-018-5713-1

Kamau, M., Mirie, W., Kimani, S., \& Mugoya, I. (2019). Effect of community based health education on knowledge and attitude towards iron and folic acid supplementation among pregnant women in Kiambu County, Kenya: A quasi experimental study. PLOS ONE, 14(11). https://doi.org/10.1371/journal.pone.0224361

Moussa, H. N., Hosseini Nasab, S., Haidar, Z. A., Blackwell, S. C., \& Sibai, B. M. (2016). Folic acid supplementation: what is new? Fetal, obstetric, long-term benefits and risks. In Future Science OA (Vol. 2, Issue 2). https://doi.org/10.4155/fsoa-2015-0015

Ng'the, H. M., Nderitu, D., \& Wanja, S. (2021). Nutrition counselling and knowledge on iron and folic acid supplementation among pregnant women in Nyeri County, Kenya. International Journal of Community Medicine And Public Health, 8(4). https://doi.org/10.18203/2394-

6040.ijcmph20211209

NGETHE, H. M., MAPESA, D. J., \& MUGAMBI, L. (2020). Relationship between compliance to Iron and Folic Acid Supplementation and Anaemia among Pregnant Women in Nyeri County, Kenya. International Journal of Scientific and Research Publications (IJSRP), 10(11). https://doi.org/10.29322/ijsrp.10.11.2020.p10 733

Noviyana, A. (2019). Peran Bidan Dalam Pemberian Suplementasi Tablet Tambah Darah (Ttd) Untuk Pencegahan Anemia Ibu Hamil Di Puskesmas II Kembaran Kabupaten Banyumas. Viva Medika: Jurnal Kesehatan, Kebidanan Dan Keperawatan, 11(02). https://doi.org/10.35960/vm.v11i02.474

Oiye, S., Juma, M., Konyole, S., \& Adan, F. (2020). The Influence of Antenatal Oral Iron and Folic Acid Side Effects on Supplementation Duration in Low-Resource Rural Kenya: A Cross-Sectional Study. Journal of Pregnancy, 2020. https://doi.org/10.1155/2020/9621831

Putri, R. N., Nirmala, S. A., Aprillani, I. K., Judistiani, T. D., \& Wijaya, M. (2020). Hubungan Karakteristik Ibu, Asupan Zat Besi, Asam Folat Dan Vitamin C Dengan Status Anemia Ibu Hamil. Jurnal Kesehatan Vokasional. https://doi.org/10.22146/jkesvo.44202

RISKESDAS. (2018). Riset Kesehatan Dasar 2018. Kementrian Kesehatan Republik Indonesia.

Schulze, K. J., Mehra, S., Shaikh, S., Ali, H., Shamim, A. A., Wu, L. S. F., Mitra, M., Arguello, M. A., Kmush, B., Sungpuag, P., Udomkesmelee, E., Merrill, R., Klemm, R. D. W., Ullah, B., Labrique, A. B., West, K. P., \& Christian, P. (2019). Antenatal multiple micronutrient supplementation compared to iron-folic acid affects micronutrient status but does not eliminate deficiencies in a randomized controlled trial among pregnant women of rural Bangladesh. Journal of Nutrition, 149(7) https://doi.org/10.1093/jn/nxz046

Stephen, G., Mgongo, M., Hussein Hashim, T., Katanga, J., Stray-Pedersen, B., \& Msuya, S. E. (2018). Anaemia in Pregnancy: Prevalence, Risk Factors, and Adverse Perinatal Outcomes in Northern Tanzania. Anemia. https://doi.org/10.1155/2018/1846280

Tinago, C. B., Annang Ingram, L., Blake, C. E., \& Frongillo, E. A. (2017). Individual and structural environmental influences on utilization of iron and folic acid supplementation among pregnant women in Harare, Zimbabwe. Maternal and Child Nutrition, 
Faletehan Health Journal, 8 (3) (2021) 173-181

https://doi.org/10.1111/mcn.12350

Ugwu, N. I., \& Uneke, C. J. (2020). Iron deficiency anemia in pregnancy in Nigeria - A systematic review. In Nigerian Journal of Clinical Practice (Vol. 23, Issue 7). https://doi.org/10.4103/njcp.njcp_197_19

Varghese, J. S., Swaminathan, S., Kurpad, A. V., \& Thomas, T. (2019). Demand and supply factors of iron-folic acid supplementation and its association with anaemia in North Indian pregnant women. PLOS ONE, 14(1). https://doi.org/10.1371/journal.pone.0210634

Wen, S. W., Guo, Y., Rodger, M., White, R. R., Yang, Q., Smith, G. N., Perkins, S. L., \& Walker, M. C. (2016). Folic acid supplementation in pregnancy and the risk of pre-eclampsia-A cohort study. PLoS ONE, 11(2).

https://doi.org/10.1371/journal.pone.0149818

Wesström, J. (2020). Safety of intravenous iron isomaltoside for iron deficiency and iron deficiency anemia in pregnancy. In Archives of Gynecology and Obstetrics (Vol. 301, Issue 5). https://doi.org/10.1007/s00404-02005509-2

WHO, De-Regil, L. M., Juan Pablo, P.-R., Metin, G., Jose, M., Mathai, M., \& Lisa, R. (2012). Guideline: Daily Iron and Folic Acid Supplementation in Pregnant Women. World Health Organization.

World health organisation. (2016). Guideline: iron supplementation in postpartum women. Geneva: WHO.

World Health Organisation, \& WHO. (2011). Haemoglobin concentrations for the diagnosis of anaemia and assessment of severity. Geneva, Switzerland: World Health Organization.

World Health Organization. (2015). WHO | Iron deficiency anaemia: assessment, prevention and control. In $\mathrm{WHO}$. 